\title{
Relationship between Dielectric Constant and Increament of Si-O bond in SiOC Film
}

\author{
Teresa $\mathbf{O h}^{1^{*}}$ \\ ${ }^{1}$ Division of Semiconductor Design, Cheongju University \\ $\mathrm{SiOC}$ 박막에서 $\mathrm{Si}-\mathrm{O}$ 결합의 증가와 유전상수의 관계 \\ 오데레사 ${ }^{*}$ \\ ${ }^{1}$ 청주대학교 반도체설계공학과
}

\begin{abstract}
SiOC films made by the inductively coupled plasma chemical vapor deposition were researched the relationship between the dielectric constant and the chemical shift. SiOC film obtained by plasma method had the main Si-O-C bond with the molecule vibration mode in the range of $930 \sim 1230 \mathrm{~cm}^{-1}$ which consists of C-O and $\mathrm{Si}-\mathrm{O}$ bonds related to the cross link formation according to the dissociation and recombination. The C-O bond originated from the elongation effect by the neighboring highly electron negative oxygen atoms at terminal $\mathrm{C}-\mathrm{H}$ bond in $\mathrm{Si}_{-} \mathrm{CH}_{3}$ of $1270 \mathrm{~cm}^{-1}$. However, the Si-O bond was formed from the second ionic sites recombined after the dissociation of $\mathrm{Si}_{-} \mathrm{CH}_{3}$ of $1270 \mathrm{~cm}^{-1}$. The increase of the Si-O bond induced the redshift as the shift of peak in FTIR spectra because of the increase of right shoulder in main bond. These results mean that SiOC films become more stable and stronger than SiOC film with dominant $\mathrm{C}-\mathrm{O}$ bond. So it was researched that the roughness was also decreased due to the high degree of amorphous structure at SiOC film with the redshift after annealing.
\end{abstract}

요 약 ICP-CVD 방법에 의해 제작된 $\mathrm{SiOC}$ 박막을 유전상수와 화학적 이동의 상관성에 대하여 조사하였다. $\mathrm{SiOC}$ 박막은 플라즈마 에너지에 의해서 해리작용과 재결합작용에 의해서 cross link 구조를 갖게 되는 Si-O 와 C-O 결합으 로 구성된 930 1230 $\mathrm{cm}^{-1}$ 영역에서 혼합된 $\mathrm{Si}-\mathrm{O}-\mathrm{C}$ 주 결합으로 이루어졌다. C-O 결합은 $1270 \mathrm{~cm}^{-1}$ 에서 보여지는 $\mathrm{Si}_{-} \mathrm{CH}_{3}$ 결합의 말단부분인 C-H 결합이 전기음성도가 큰 산소에 의해서 끌리는 효과로부터 만들어진 결합이다. 그러 나 $\mathrm{Si}-\mathrm{O}$ 결합은 $\mathrm{Si}-\mathrm{CH}_{3}$ 결합이 분해되고 난뒤 2차 이온결합에 의해서 만들어진 결합이다. $\mathrm{Si}-\mathrm{O}$ 결합의 증가는 주결합 에서 오른쪽 결합이 증가하기 때문이며, FTIR 스펙트라에 의해서 red shift로 나타났다. 이러한 결과는 SiOC 박막이 보다 더 안정되고 강한 박막임을 의미한다. 그래서 $\mathrm{SiOC}$ 박막은 열처리 후 비정질도가 높고 거칠기가 감소되는 것을 확인하였다.

Key Words : SiOC film, Polarization, Blueshift, Hardness, Dielectric constant

\section{Introduction}

Introduction SiOC film with low dielectric constant (low-k) has been focused on the promising insulator, which can be replaced the silicon dioxide film, because of increasing of crosstalk noise and signal delay time in using of $\mathrm{SiO}_{2}$ film in ultra large scale integrated circuits
(ULSI) system[1-7]. The reduction of the dielectric constant of SiOC film is due to decreasing the polarization or increasing the porosity. But pores in the thin film decreases the hardness and leads to problems in making multi level integration. On the other hand, the SiOC film due to the low polarization has good properties in view of the mechanical, electrical and thermal stability,

${ }^{*}$ Corresponding Author : Teresa Oh(teresa@cju.ac.kr) 
because the $\mathrm{C}-\mathrm{H}$ bond elongation effect also reduces the ionic polarization in SiOC film[8-12]. The amorphous structure owing to the ionic polarization decreases the polarization and dielectric constant in SiOC film.

The paper was prepared SiOC films with various flow rate ratios deposited by inducitive coupled plasma chemical vapor deposition (ICP-CVD). It was studied the correlation between the chemical shift in FTIR and the dielectric constant, which was related with the ionic polarization.

\section{Experiment method}

The low-k SiOC films were obtained using the mixed gases of oxygen and methyltrimethoxysilance (MTMS) by inductive coupled plasma chemical vapor deposition (ICP-CVD). The SiOC films were processed with various annealing temperature at $500^{\circ} \mathrm{C}$. The MTMS was vaporized and carried by argon gas at $35{ }^{\circ} \mathrm{C}$ from a thermostatic bubbler. The low-k SiOC films were prepared by various flow rate ratios of MTMS precursors, but the total gas flow rate was $15 \mathrm{sccm}$. The base pressure was 3 Torr and the rf power was $800 \mathrm{~W}$ in each experiment. The chemical properties of SiOC film was researched by Fourier Transform Infrared spectrometer (FTIR, Galaxy 7020A). The thickness of the film was measured by the Ellipsometer, and the dielectric constant of SiOC film was researched from the $\mathrm{C}-\mathrm{V}$ (capacitance-voltage) measurement at $1 \mathrm{MHz}$ using the $\mathrm{HP} 4284 \mathrm{~A}$ on the MIS ( $\mathrm{Al} / \mathrm{SiOC}$ film/Si substrate) structure.

\section{Results and discussion}

SiOC film was deposited by chemical vapor deposition. The gas precursor is dissociated into ions, cations and radicals which are controlled by the bond dissociated energy. These ions, cations and radicals trend toward more stable bonds than before. In the case of ultra low-k materials, many alkyl groups generate a number of Si-R, $\mathrm{Si}-\mathrm{H}$ bonds. Generally, SiOC film decreases the dielectric constant due to the ionic polarization witch is manufactured by the control of density due to the flow rate ratios during the deposition[13-15]. The chemical reaction during the deposition is carried out and generated many sites as given by the following equations.

$$
\begin{aligned}
& \mathrm{Si}-\mathrm{CH}_{3}+\mathrm{O}_{2} \rightarrow \mathrm{Si}-\mathrm{O}+\mathrm{O}-\mathrm{CH}_{3} \\
& \mathrm{O}-\mathrm{CH}_{3}+\mathrm{Si} \rightarrow \mathrm{O}-\mathrm{Si}-\mathrm{CH}_{3} \\
& \mathrm{Si}-\mathrm{CH}_{3}+\mathrm{Si}-\mathrm{CH}_{3} \rightarrow \mathrm{Si}-\mathrm{CH}_{2}-\mathrm{CH}_{3}+\mathrm{Si}-\mathrm{H} \\
& \mathrm{Si}-\mathrm{H}+\mathrm{Si}-\mathrm{O} \rightarrow \mathrm{Si}+\mathrm{Si}-\mathrm{OH}
\end{aligned}
$$

In the case of ultra low-k materials, many alkyl groups generate a number of $\mathrm{Si}-\mathrm{R}, \mathrm{Si}-\mathrm{H}$ bonds as shown in the equation (3) and (4). On the other hand, the equation of (1) and (2) is the reaction at a lot of oxygen flow rate ratio. Generally, SiOC film decreases the dielectric constant due to the ionic polarization witch is manufactured by the control of density due to the flow rate ratios during the deposition. Basically, we infer that the ionic bonds recombined from the reaction of (1) and (2) are stronger and more stable than that of (3) and (4).

Figure 1 is the dielectric constant obtained from the $\mathrm{C}-\mathrm{V}$ measurement using MIS structure. The dielectric constant decreased at the annealed samples of 4,9 and 13 , because of the oxidation reaction and $\mathrm{H}_{2} \mathrm{O}$ evaporation during the annealing process. It is inferred the variation of polarity obtained from the chemical reaction between different polar sites such as $\mathrm{OH}$ and $\mathrm{CH}$ groups from the change of dielectric constant of as deposited films according to the flow rate ratios. The deposited SiOC film reduces the dielectric constant once again by the oxidation annealing process due to the $\mathrm{H}_{2} \mathrm{O}$ evaporation.

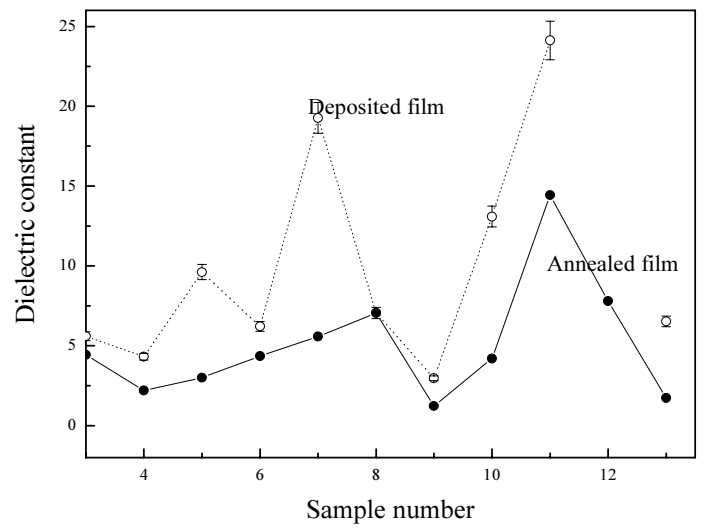

[Fig. 1] Dielectric constant of SiOC film with various flow rate ratios and annealing temperature at 500 ${ }^{\circ} \mathrm{C}$. 

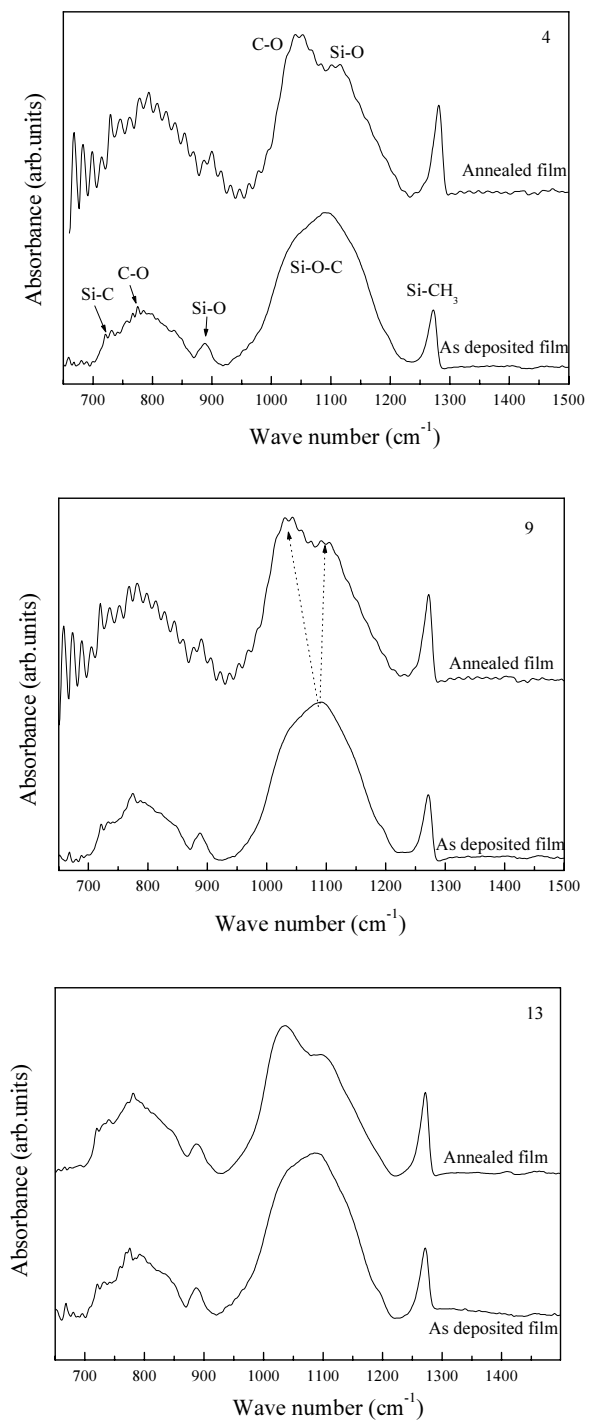

[Fig. 2] Difference of FTIR spectra due to the annealing effect in SiOC films with low dielectric constant, (a) sample 4, (b) sample 9, (c) sample 13.

Figure 2 shows the FTIR spectra of $650 \sim 1500 \mathrm{~cm}^{-1}$ of as deposited and annealed films about samples 4, 9 and 13 with low dielectric constant. FTIR spectra of SiOC film consist of the Si-O-C bond of $930 \sim 1230 \mathrm{~cm}^{-1}$, the Si-O-C bond of $650 \sim 930 \mathrm{~cm}^{-1}$ and $\mathrm{Si}_{-}-\mathrm{CH}_{3}$ bond of $1270 \mathrm{~cm}^{-1}$. The main Si-O-C bond of $930 \sim 1230 \mathrm{~cm}^{-1}$ is composed of the $\mathrm{C}-\mathrm{O}$ bond and Si-O cross-link bond. The Si-O-C bond of $930 \sim 1230 \mathrm{~cm}^{-1}$ moved to lower frequency, and split two peaks after annealing process. In the main $\mathrm{Si}-\mathrm{O}-\mathrm{C}$ bond, the Si-O cross-link bond as right shoulder increased after annealing and this effect induced the red shift at the main bond in FTIR spectra. In view of the annealing, two $\mathrm{OH}$ bonds in $\mathrm{R}-\mathrm{OH}, \mathrm{Si}-\mathrm{OH}, \mathrm{CH}$ or $\mathrm{OH}$ bonds react with each others and make $\mathrm{H}_{2} \mathrm{O}$ sites witch is the reason of increasing the dielectric constant in the film. But $\mathrm{H}_{2} \mathrm{O}$ sites evaporate during the annealing at high temperature. This oxidation reaction is given by the following equation (5) (7).

$$
\begin{aligned}
& \mathrm{CH}+\mathrm{OH} \rightarrow \mathrm{H}_{2} \mathrm{O} \uparrow+\mathrm{C} \\
& \mathrm{Si}-\mathrm{OH}+\mathrm{Si}-\mathrm{OH} \rightarrow \mathrm{H}_{2} \mathrm{O} \uparrow+\mathrm{Si}-\mathrm{O}-\mathrm{Si} \\
& \mathrm{CH}+5 \mathrm{OH} \rightarrow 3 \mathrm{H}_{2} \mathrm{O} \uparrow+\mathrm{CO}_{2}
\end{aligned}
$$

The oxidation reaction using the annealing generates two split bonds such as the Si-O cross link network and $\mathrm{C}-\mathrm{O}$ bonds in the main bond of $930 \sim 1230 \mathrm{~cm}^{-1}$ of FTIR spectra as shown in Fig.2 and the equation (5) (7). Increasing the $\mathrm{Si}-\mathrm{O}$ cross link bond as right shoulder bond means that the annealed film becomes more stable and stronger than as deposited film. This effect induces to shift lower frequency in FTIR spectra and decrease the dielectric constant of SiOC film.

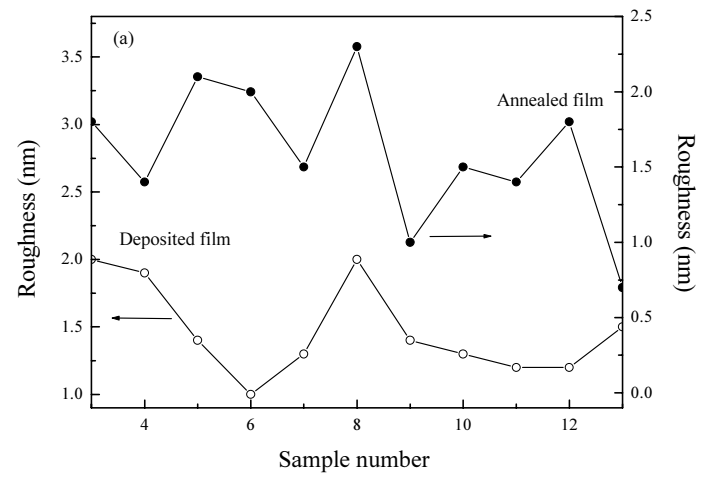

[Fig. 3] Roughness in SiOC film with various flow rate ratios and annealing temperatures.

Figure 3 shows the roughness of SiOC films with various flow rate ratios and annealing process. The increase of roughness at annealed film results from the increase of the carbon content after annealing by the equation (5) and (7). The roughness decreases at the annealed films 4, 9 and 13 with the red shift. The roughness is related to the migration of $\mathrm{Si}-\mathrm{O}-\mathrm{C}$ main bond to the red shift in FTIR spectra and the lowering of the dielectric constant. The oxidation reaction due to the annealing process not only progress the stability of the 
final film by the reduction of surface energy but also improve the degree of amorphism which needs to decrease the dielectric constant in low-k materials.
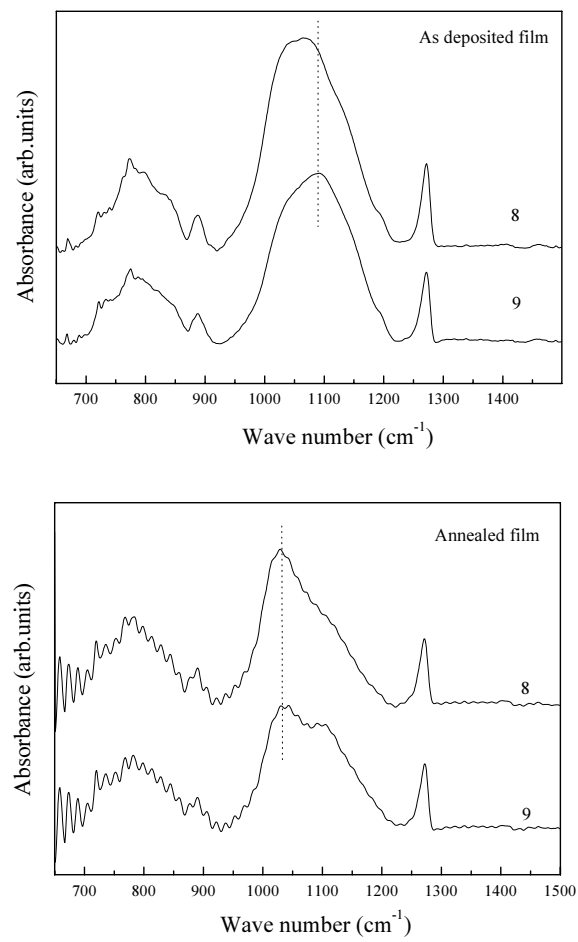

[Fig. 4] Comparison between samples 8 and 9 (a) as deposited film, (b) annealed film at $500{ }^{\circ} \mathrm{C}$.

Figure 4 shows the relationship of lowering the dielectric constant in SiOC film due to the red shift in the main bond and the increase of peak intensity in Si-O cross link bond.

Figure 4(a) shows the decreasing dielectric constant at sample 8 with the red shift from the comparison of FTIR spectra between as deposited SiOC films 8 and 9. The peak of SiOC main bond at sample 8 shifts lower frequency than that of sample 9. The dielectric constant of sample 8 also decreased in comparison with that of sample 9 as shown in Fig.1. We infer that the redshift induces the lowering the dielectric constant in SiOC film.

Figure 4(b) is the chemical shift of the Si-O cross link bond obtained from the FTIR spectra at annealed films of 8 and 9 . The main bond of sample 9 is split by two peaks after annealing, but the sample 8 has almost one peak with weak right shoulder peak. The right shoulder peak of the main mode at sample 9 originates from the increase of Si-O cross-link bond, satisfying condition as a low-k material. Increase of the $\mathrm{Si}-\mathrm{O}$ cross link bond induces the lowering the dielectric constant and roughness as previous mentioned. The dielectric constant of sample 9 with high intensity of Si-O cross link bond decreases in comparison with that of sample 8 as shown in Fig. 1.

\section{Conclusion}

To research the origin of variation of the bonding structure of SiOC film after annealing process, the characteristic of SiOC film was researched by FTIR spectra. The gas precursor was dissociated by the plasma energy to become many ions, cations and electrons. These sites were recombined according to the balanced formation by the equilibrium of the repulsive and attractive forces during the deposition. The hydroxyl group was evaporated by the annealing and then decreased the dielectric constant of SiOC film. The main bond of SiOC film near $1000 \mathrm{~cm}^{-1}$ consisted of the $\mathrm{C}-\mathrm{O}$ and $\mathrm{Si}-\mathrm{O}$ bonds. The bond of right shoulder $\mathrm{Si}-\mathrm{O}$ in the main bond was increased after annealing process and showed the redshift in FTIR spectra, which was related with the reduction of the dielectric constant and roughness. Because the charge dispersion of cationsin the dissociated sites such as ions, cations and electrons was induced the stability of the surface energy and decreased the roughness and the dielectric constant.

\section{References}

[1] Y. L. Hsu, Y. K. Fang, Y. T. Chiang, T. H. Chou and F. C. N Hong, Jpn. J. Appl. Phys. 46, 530, 2007.

[2] Z. Q. Fang, B. Claflin, D.C. Look and G. C. Farlow, Journal of Electronic Materials, 36, 307, 2007.

[3] M. S. Kim, J. H. Kim and E. K. Kim, Journal of the Korean Physical Society, 48, 1552, 2006.

[4] P. de Rouffignac, Z. Li, and R. G. Gordon, Electrochemical and Solid State Letters, 7, G360, 2004.

[5] P. Jakob, B. N. J. Persson, Journal of Chemical 
Physics, 109, 8641, 1998.

[6] J. Heo, H. J. Kim, J. H. Han, J. W. Shon. Thin Solid Films, 2007, 515: 5035-5039.

[7] H. Tavana, F. Simon, K. Grundke, D. Y. Kwon, M. L. Hair, A. W. Neumann, Journal of Colloid and Interface Science, 291, 497, 2005.

[8] T. Oh, IEEE Trans. Nanotechnology, 5, 23, 2006.

[9] R. Navamathavan and C. K. Choi, Journal of the Korean Physical Society, Vol. 48, pp. 1675-1679, 2006.

[10] T. Oh, Jpn. J. Appl. Phys. Vol. 44, pp.4103-4107, 2005.

[11] J. Widodo, W. Lu, S. G. Mhaisalkar, L. C. Hsia, P. Y. Tan, L. Shen and K. Y. Zeng, Thin Solid Films, 462-463, 213-218, 2004.

[12] A. Grill and D. A. Neumayer, J. Appl. Phys. Vol. 94, pp. 6697-6707,2003.

[13] M. K. Mazumder, R. Moriyama, D. watanabe, C. Kimura, H. Aoki and T. Sugino, Jpn. J. Appl. Phys. 46, 2007. 2006-2010.

[14] L. D. Yu, S. Lei, Z. S. Dong, W. Yi, L. X. Yan and H. R. Qi, Chin. Phys. Soc. 16, 240, 2007.

[15] M. Damayanti, J. Widodo, T. Sritharan, S. G. Mhaisalkar, W. Lu, Z. H. Gan, K. Y. Zeng and L. C. Hsia, Materials Science and Engineering B, 121, 193, 2005.

\section{오 데레사(Teresa Oh)}

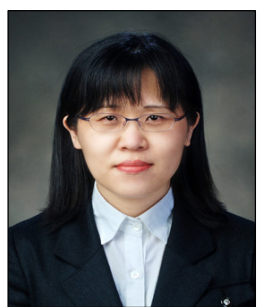

- 2000년 2월 : 제주대학교 (박사)

- 2005년 3월 현재 : 청주대학 교 반도체설계공학과 교수

<관심분야>

물질재료, 반도체소자, 태양전지 